\title{
SEM, EDS AND XPS ANALYSIS OF NANOSTRUCTURED COATING FORMED ON NiTi BIOMATERIAL ALLOY BY PLASMA ELECTROLYTIC OXIDATION (PEO)
}

\author{
Krzysztof Rokosz, Tadeusz Hryniewicz, Steinar Raaen
}

Original scientific paper

Plasma Electrolytic Oxidation (PEO) of NiTi alloy was studied in the electrolyte consisting generally of concentrated orthophosphoric acid with an addition of copper II nitrate. The PEO process was used to obtain a nanostructured coating on the Nitinol surface. The surface layer analyses methods, such as scanning electron microscopy (SEM) with the energy-dispersive X-ray spectroscopy (EDS), and X-ray photoelectron spectroscopy (XPS), allowed determining the structure and composition of the most expected coatings and revealing the conditions for obtaining them. It was found that the porous PEO coating obtained in the electrolyte containing copper nitrate in an amount higher than $1,6 \mathrm{~mol} / \mathrm{L}$ consists mainly of copper-titanium-nickel phosphates. Moreover, in comparison with matrix, the emergence of carcinogenic nickel appearing in the coating fortunately appears in very small quantities, i.e. below 1 at $\%$.

Keywords: biomaterials; coatings; electrochemical techniques; energy dispersive X-ray spectroscopy (EDS); NiTi alloy; X-ray photoelectron spectroscopy (XPS)

\section{SEM, EDS i XPS analiza nanostrukturirane prevlake koja se stvara na leguri od NiTi biomaterijala plasma elektrolitičkom oksidacijom (PEO)}

Izvorni znanstveni članak Plasma elektrolitička oksidacija (PEO) NiTi legure proučavana je u elektrolitu koji se uobičajeno sastojao od koncentrirane ortofosforične kiseline s dodatkom nitrata bakra II. Taj se PEO postupak primijenio za dobivanje nanostrukturirane prevlake na Nitinol površini. Metode analize površinskog sloja kao što su skeniranje elektronskim mikroskopom (SEM) s energetski disperzivnom rendgenskom spektroskopijom (EDS) i rendgenskom fotoelektronskom spektroskopijom (XPS), omogućile su određivanje strukture i sastava najočekivanijih prevlaka i otkrivanje uvjeta za njihovo dobivanje. Ustanovilo se da se porozna PEO prevlaka dobivena u elektrolitu koji je sadržavao bakreni nitrat u količini većoj od 1,6 mol/L sastoji uglavnom od fosfata bakra-titanija-nikla. Uz to, u usporedbi s matricom, karcinogeni nikal u prevlaci srećom se javlja u vrlo malim količinama, tj. ispod 1 at\%.

Ključne riječi: biomaterijali; prevlake; elektrokemijske metode; energetski disperzivna rendgenska spektroskopija (EDS); legura NiTi; rendgenska fotoelektronska spektroskopija (XPS)

\section{Introduction}

Nitinol (nickel-titanium alloy), similar as other metals (titanium, tantalum, niobium, zirconium) and their alloys, can be treated inter alia by Electropolishing (EP) and Magnetoelectropolishing (MEP) $[1 \div 7]$, as well as by Plasma Electrolytic Oxidation - PEO (Micro Arc Oxidation - MOA) $[8 \div 23]$. Concerning the nickeltitanium alloy surface treatment, our electrochemical experiments show that generally the electropolishing process is mostly run when using the voltage under $80 \mathrm{~V}$. With increasing the voltage of the electrochemical treatment, the plasma in electrolyte is created and then the conditions for the plasma electrolytic oxidation (PEO) treatment are achieved. Another important feature of the PEO process is the electrolyte composition. In fact it is composed of a concentrated acid, usually orthophosphoric, and a salt of the bactericidal metals, e.g. silver $[24 \div 26]$ or copper $[27 \div 29]$. These metals are important to cooperate and be compatible with the human being tissue.

In present work, the study of nanostructured coating obtained on one of the intermetallic compounds used for biomaterials, known as Nitinol, is presented. The PEO process was studied to obtain the porous coating on NiTi surface. The analyses methods used in this work, such as SEM, EDS, and XPS, allowed determining the structure and composition of the most expected coatings and revealing the conditions for obtaining them.

\section{Method}

The chemical composition of $\mathrm{NiTi}$ rectangular samples with dimensions $5 \times 30 \times 1 \mathrm{~mm}$, which were used in experiments, is presented in Fig. 1. The PEO process was done at average voltage $450 \mathrm{~V}$ with pulsation of $300 \mathrm{~Hz}$ with amplitude of $92 \mathrm{~V}$. The detailed description of the set up dedicated to PEO (MOA) process as well as to SEM, EDS and XPS equipment, is presented in references $[18 \div 21]$.

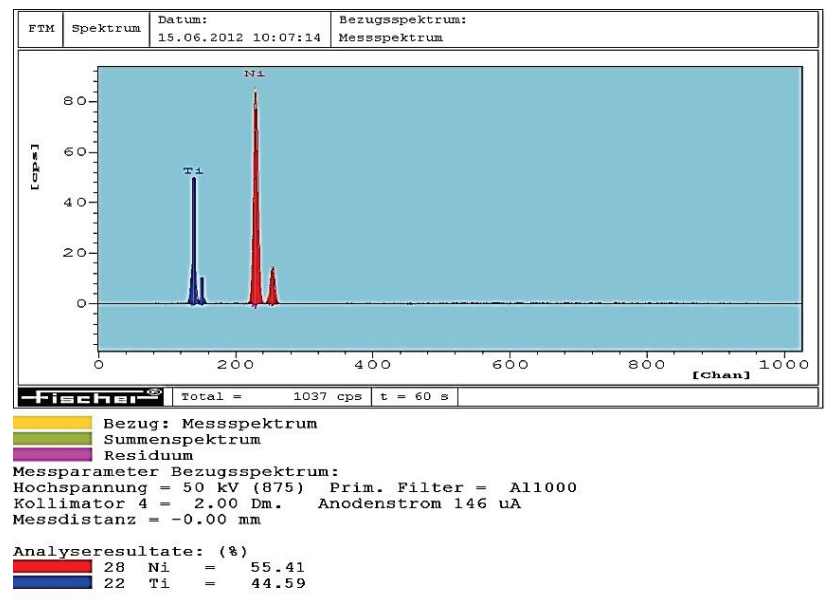

Figure 1 EDS results of NiTi alloy before treatment (as received)

\section{Results and discussion}

In Fig. 2, the SEM images of surface layer formed on NiTi alloy after the PEO treatment at voltage of $450 \mathrm{~V}$ in 
$0,05 \mathrm{~mol} / \mathrm{L}$ of $\mathrm{Cu}\left(\mathrm{NO}_{3}\right)_{2}$ in $\mathrm{H}_{3} \mathrm{PO}_{4}$ electrolyte, are shown. One may notice that obtained surface is not porous within small amount of copper $(0,4 \pm 0,2 \mathrm{wt} \%)$, the results are displayed in Fig. 3 and Tab. 1.

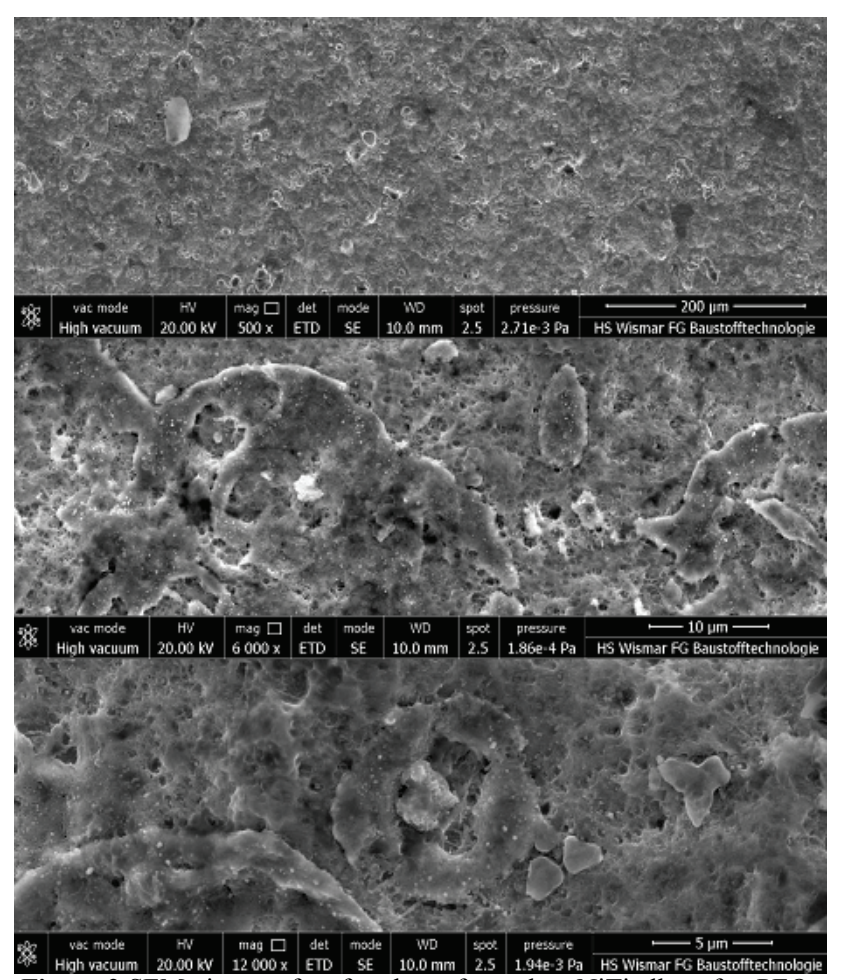

Figure 2 SEM picture of surface layer formed on NiTi alloy after PEO at voltage of $450 \mathrm{~V}$ in $0,05 \mathrm{~mol} / \mathrm{L}$ of $\mathrm{Cu}\left(\mathrm{NO}_{3}\right)_{2}$ in $\mathrm{H}_{3} \mathrm{PO}_{4}$ electrolyte

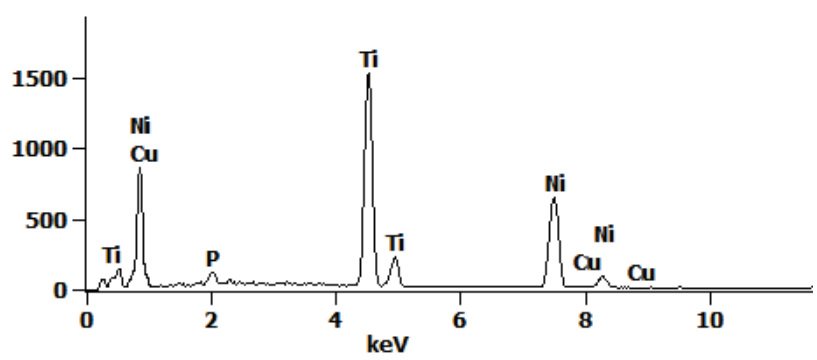

Figure 3 EDS result of surface layer formed on NiTi alloy after PEO at voltage of $450 \mathrm{~V}$ in $0,05 \mathrm{~mol} / \mathrm{L}$ of $\mathrm{Cu}\left(\mathrm{NO}_{3}\right)_{2}$ in $\mathrm{H}_{3} \mathrm{PO}_{4}$ electrolyte

Table 1 Quantitative results of weight and atomic concentration of selected elements on the basis of EDS presented in Fig. 3

\begin{tabular}{|c|c|c|c|c|}
\hline $\begin{array}{c}\text { Element } \\
\text { lines }\end{array}$ & $\mathrm{wt} \%$ & $\begin{array}{c}\text { Error } \\
\mathrm{wt} \%\end{array}$ & $\mathrm{at} \%$ & $\begin{array}{c}\text { Error } \\
\mathrm{at} \%\end{array}$ \\
\hline $\mathrm{O} \mathrm{K}$ & 34,4 & --- & 63,5 & $\pm 19,1$ \\
\hline $\mathrm{P} \mathrm{K}$ & 0,7 & $\pm 0,1$ & 0,7 & $\pm 0,1$ \\
\hline $\mathrm{Ti} \mathrm{K}$ & 28,2 & $\pm 0,3$ & 17,4 & $\pm 0,3$ \\
\hline $\mathrm{Ni} \mathrm{K}$ & 36,3 & $\pm 0,6$ & 18,2 & $\pm 0,6$ \\
\hline $\mathrm{Cu} \mathrm{K}$ & 0,4 & $\pm 0,2$ & 0,2 & $\pm 0,2$ \\
\hline
\end{tabular}

It should be also noted that the obtained coating contains a small amount of phosphorus $(0,7 \pm 0,1 \mathrm{wt} \%)$ with very large amount of oxygen what may indicate that the coating consists mainly of oxides and hydroxides with a small amount of phosphates. It was recorded that there is relatively a high amount of titanium $(28,2 \pm 0,3 \mathrm{wt} \%)$ and nickel $(36,3 \pm 0,6 \mathrm{wt} \%)$. Due to the carcinogenic action of nickel, the obtained coating cannot be used for medical applications as a biomaterial. On the other hand, however, it should be noted that a part of titanium and nickel signal may come from the substrate (matrix), what would mean that the obtained PEO oxide layer is very thin. In the summary it should be emphasized that the coating obtained on NiTi alloy after the PEO at voltage of $450 \mathrm{~V}$ in $0,05 \mathrm{~mol} / \mathrm{L}$ of $\mathrm{Cu}\left(\mathrm{NO}_{3}\right)_{2}$ in $\mathrm{H}_{3} \mathrm{PO}_{4}$ electrolyte cannot be used as a biocompatible metallic material.

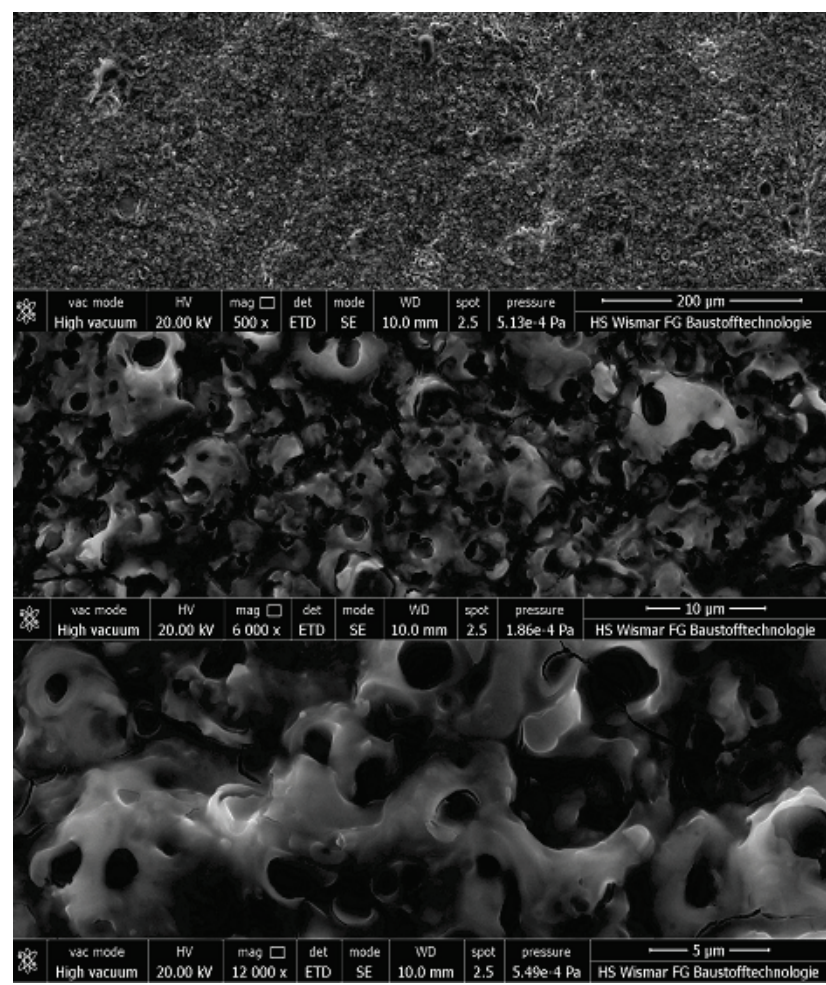

Figure 4 SEM picture of surface layer formed on NiTi alloy after PEO at voltage of $450 \mathrm{~V}$ in $1,60 \mathrm{~mol} / \mathrm{L}$ of $\mathrm{Cu}\left(\mathrm{NO}_{3}\right)_{2}$ in $\mathrm{H}_{3} \mathrm{PO}_{4}$ electrolyte

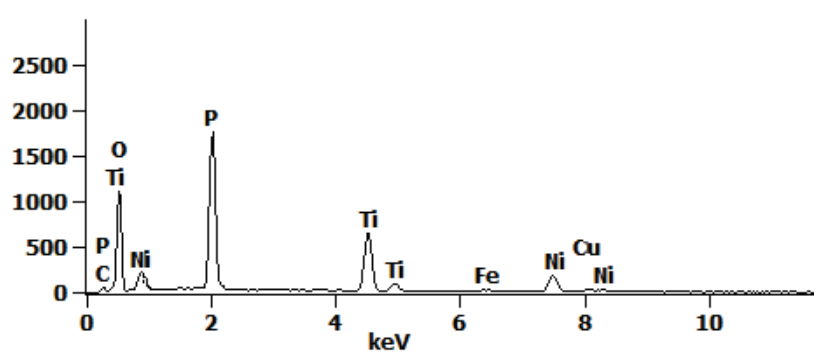

Figure 5 EDS result of surface layer formed on NiTi alloy after PEO at voltage of $450 \mathrm{~V}$ in $1,60 \mathrm{~mol} / \mathrm{L}$ of $\mathrm{Cu}\left(\mathrm{NO}_{3}\right)_{2}$ in $\mathrm{H}_{3} \mathrm{PO}_{4}$ electrolyte

In Fig. 4, the SEM images of surface layer created on NiTi alloy after the PEO at voltage of $450 \mathrm{~V}$ in 1,60 $\mathrm{mol} / \mathrm{L}$ of $\mathrm{Cu}\left(\mathrm{NO}_{3}\right)_{2}$ in $\mathrm{H}_{3} \mathrm{PO}_{4}$ electrolyte, are presented. The displayed pictures clearly prove that obtained surface is porous and the EDS measurements results show (Fig. 5 and Tab. 2) it contains copper in the amount of $3,3 \pm 0,3 \mathrm{wt} \%$. The nickel $(13,9 \pm 0,6 \mathrm{wt} \%)$ and titanium $(17,6 \pm 0,3 \mathrm{wt} \%)$ amounts indicate that the obtained coating is thicker than the one formed in the electrolyte within $0,05 \mathrm{~mol} / \mathrm{L}$ of $\mathrm{Cu}\left(\mathrm{NO}_{3}\right)_{2}$ in $\mathrm{H}_{3} \mathrm{PO}_{4}$. Additionally, the amount of phosphorus, as detected by EDS and equaling $19,1 \pm 0,2 \mathrm{wt} \%$, suggests that the coating is composed of oxides/hydroxides and phosphates. In this case one should emphasize that the coating obtained on $\mathrm{NiTi}$ alloy after the PEO at voltage of $450 \mathrm{~V}$ in $1,6 \mathrm{~mol} / \mathrm{L}$ of $\mathrm{Cu}\left(\mathrm{NO}_{3}\right)_{2}$ in $\mathrm{H}_{3} \mathrm{PO}_{4}$ electrolyte can be considered as a biocompatible one. 
Table 2 Quantitative results of weight and atomic concentration of selected elements on the basis of EDS presented in Fig. 5

\begin{tabular}{|c|c|c|c|c|}
\hline $\begin{array}{c}\text { Element } \\
\text { lines }\end{array}$ & $\mathrm{wt} \%$ & $\begin{array}{c}\text { Error } \\
\mathrm{wt} \%\end{array}$ & $\mathrm{at} \%$ & $\begin{array}{c}\text { Error } \\
\mathrm{at} \%\end{array}$ \\
\hline $\mathrm{O} \mathrm{K}$ & 46,1 & --- & 69,4 & $\pm 1,9$ \\
\hline $\mathrm{P} \mathrm{K}$ & 19,1 & $\pm 0,2$ & 14,8 & $\pm 0,3$ \\
\hline $\mathrm{Ti} \mathrm{K}$ & 17,6 & $\pm 0,3$ & 8,9 & $\pm 0,3$ \\
\hline $\mathrm{Ni} \mathrm{K}$ & 13,9 & $\pm 0,6$ & 5,6 & $\pm 0,4$ \\
\hline $\mathrm{Cu} \mathrm{K}$ & 3,3 & $\pm 0,3$ & 1,3 & $\pm 0,2$ \\
\hline
\end{tabular}

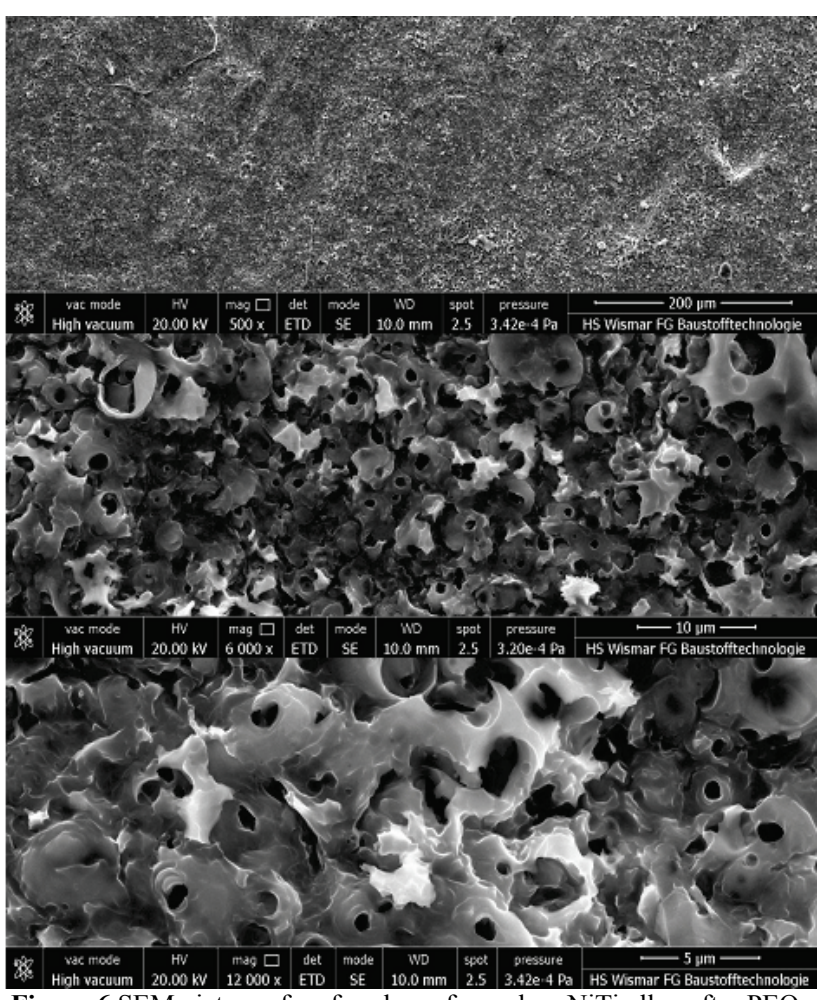

Figure 6 SEM picture of surface layer formed on NiTi alloy after PEO at voltage of $450 \mathrm{~V}$ in $3,20 \mathrm{~mol} / \mathrm{L}$ of $\mathrm{Cu}\left(\mathrm{NO}_{3}\right)_{2}$ in $\mathrm{H}_{3} \mathrm{PO}_{4}$ electrolyte

In Fig. 6, the SEM pictures of the surface layer formed on NiTi alloy after the PEO at voltage of $450 \mathrm{~V}$ in $3,2 \mathrm{~mol} / \mathrm{L}$ of $\mathrm{Cu}\left(\mathrm{NO}_{3}\right)_{2}$ in $\mathrm{H}_{3} \mathrm{PO}_{4}$ electrolyte are given. The results show that the obtained surface is porous and the surface layer contains the highest amount of copper $(5,2 \pm 0,6 \mathrm{wt} \%)$, as presented in Fig. 7 and Tab. 3. It should be noted that the pore structure is different than that one created in electrolyte containing $1,60 \mathrm{~mol} / \mathrm{L}$ of $\mathrm{Cu}\left(\mathrm{NO}_{3}\right)_{2}$ in $\mathrm{H}_{3} \mathrm{PO}_{4}$ electrolyte. The amount of phosphorus, which is equal to $21,2 \pm 0,2 \mathrm{wt} \%$, suggests that the coating is enriched with a high amount of phosphates combined with oxides/hydroxides. These conditions of the $\mathrm{PEO}$ experiment, performed at the voltage of $450 \mathrm{~V}$ in $3,2 \mathrm{~mol} / \mathrm{L}$ of $\mathrm{Cu}\left(\mathrm{NO}_{3}\right)_{2}$ in $\mathrm{H}_{3} \mathrm{PO}_{4}$ electrolyte, allow to conclude that the coating obtained on NiTi alloy can be considered as a biocompatible one. The nickel $(10,8 \pm 0,5 \mathrm{wt} \%)$ and titanium $(14,8 \pm 0,3 \mathrm{wt} \%)$ contents clearly indicate that the obtained coating is most likely the thickest one, with the thickness bigger than that of two others discussed above.

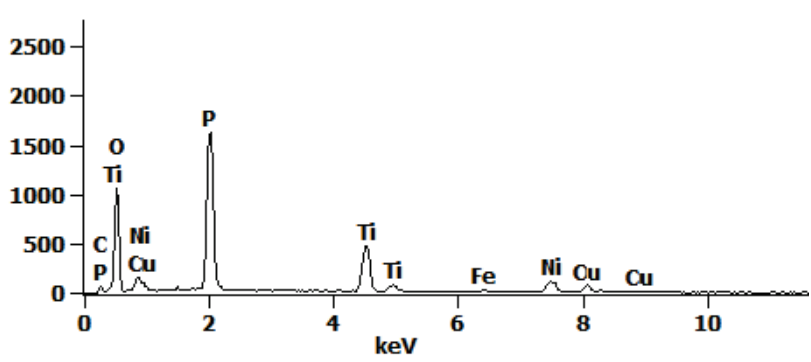

Figure 7 EDS result of surface layer formed on NiTi alloy after PEO at voltage of 450 in $3,20 \mathrm{~mol} / \mathrm{L}$ of $\mathrm{Cu}\left(\mathrm{NO}_{3}\right)_{2}$ in $\mathrm{H}_{3} \mathrm{PO}_{4}$ electrolyte

Because by the EDS measurements the signals of matrix cannot be separated from the signals of coatings, to get more results the additional measurements, i.e. coming from the X-ray Photoelectron Spectroscopy (XPS), were planned. The XPS measurements of the surface layer formed on NiTi alloy after the PEO at voltage of $450 \mathrm{~V}$ in $3,20 \mathrm{~mol} / \mathrm{L}$ of $\mathrm{Cu}\left(\mathrm{NO}_{3}\right)_{2}$ in $\mathrm{H}_{3} \mathrm{PO}_{4}$ electrolyte, were performed. The most important task of the XPS study was to demonstrate the contents of chemical elements coming from coatings as well as to find their chemical states.

Table 3 Quantitative results of weight and atomic concentration of selected elements on the basis of EDS presented in Fig.7

\begin{tabular}{|c|c|c|c|c|}
\hline $\begin{array}{c}\text { Element } \\
\text { lines }\end{array}$ & $\mathrm{wt} \%$ & $\begin{array}{c}\text { Error } \\
\mathrm{wt} \%\end{array}$ & at\% & $\begin{array}{c}\text { Error } \\
\text { at } \%\end{array}$ \\
\hline $\mathrm{O} \mathrm{K}$ & 48 & --- & 70,5 & $\pm 1,7$ \\
\hline $\mathrm{P} \mathrm{K}$ & 21,2 & $\pm 0,2$ & 16 & $\pm 0,3$ \\
\hline $\mathrm{Ti} \mathrm{K}$ & 14,8 & $\pm 0,3$ & 7,3 & $\pm 0,3$ \\
\hline $\mathrm{Ni} \mathrm{K}$ & 10,8 & $\pm 0,5$ & 4,3 & $\pm 0,4$ \\
\hline $\mathrm{Cu} \mathrm{K}$ & 5,2 & $\pm 0,6$ & 1,9 & $\pm 0,4$ \\
\hline
\end{tabular}

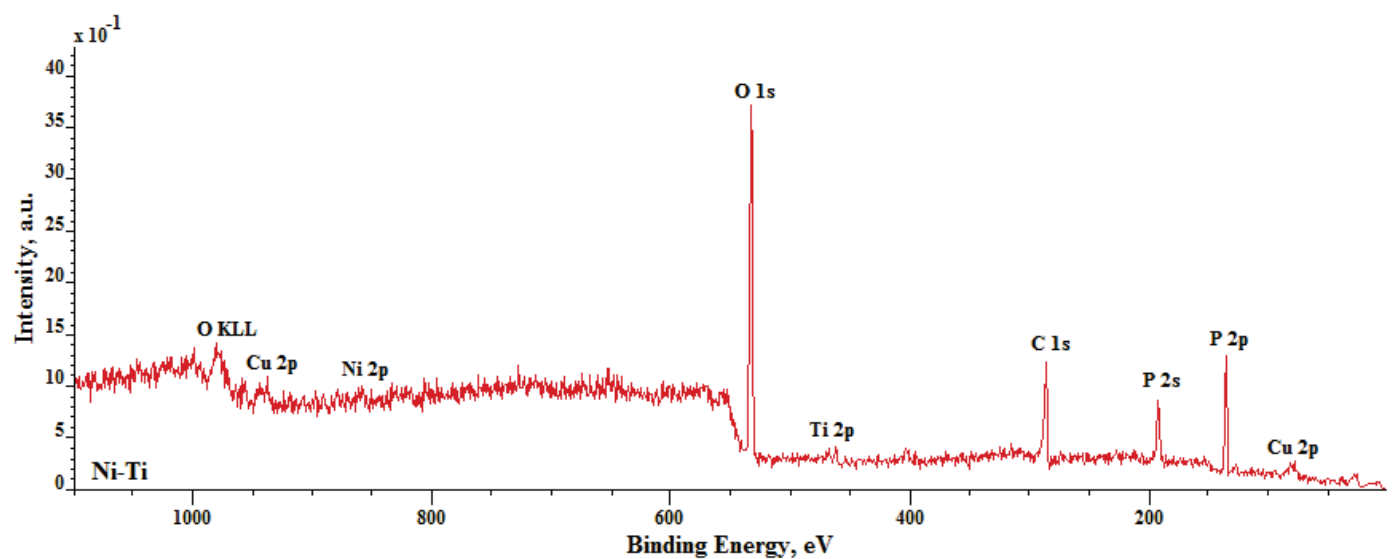

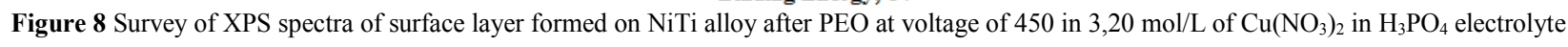


In Fig. 8, the survey of XPS spectra of the surface layer formed on NiTi alloy after the PEO treatment at the voltage of $450 \mathrm{~V}$ in $3,20 \mathrm{~mol} / \mathrm{L}$ of $\mathrm{Cu}\left(\mathrm{NO}_{3}\right)_{2}$ in $\mathrm{H}_{3} \mathrm{PO}_{4}$ electrolyte, is presented. In the survey spectrum there are visible the big signals coming from titanium (Ti $2 p$ ), nickel (Ni 2p), copper ( $\mathrm{Cu} 2 \mathrm{p})$, phosphorus (P $2 p)$ as well as these referred to oxygen $(\mathrm{O} 1 \mathrm{~s})$ and carbon $(\mathrm{C} 1 \mathrm{~s})$.
From these data it follows that the PEO coating is composed mainly of phosphorus and oxygen with a small amount of copper, titanium and nickel. In order to better determine the chemical composition of the PEO coating, the high resolution XPS measurements were performed, which are given in Fig. 9.
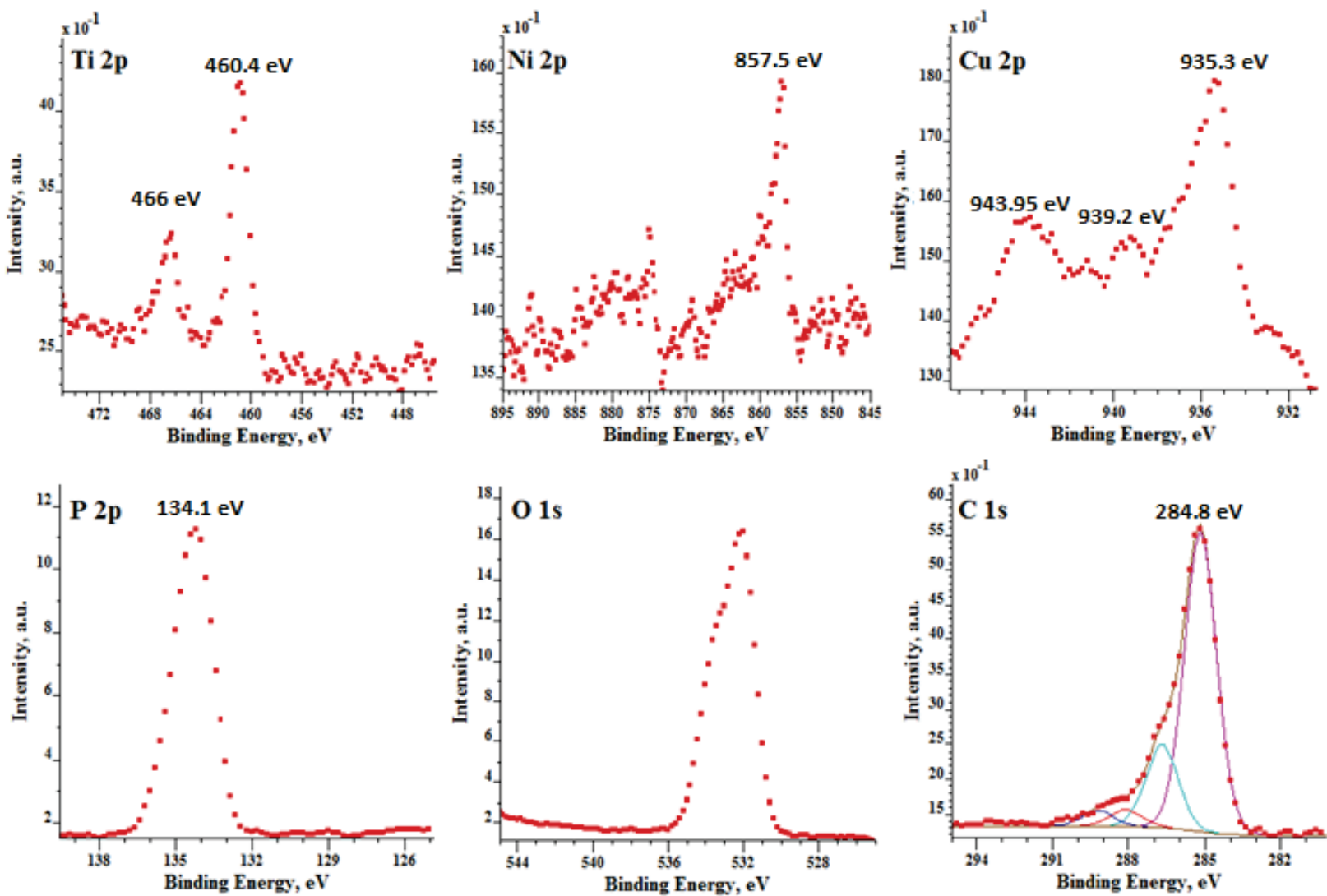

Figure 9 XPS high resolution spectra of surface layer formed on NiTi alloy after PEO

Table 4 Total chemical composition of carbon contaminations and PEO coating formed on $\mathrm{NiTi}$, at $\%$

\begin{tabular}{|c|c|c|c|c|c|}
\hline \multicolumn{7}{|c|}{$10 \mathrm{~nm}$ of PEO layer on NiTi, at\% } \\
\hline Titanium & Nickel & Copper & Phosphorus & Oxygen & Carbon \\
\hline 0,8 & 0,6 & 1,3 & 18,0 & 51,6 & 27,7 \\
\hline
\end{tabular}

Table 5 Carbon contamination of PEO coating formed on NiTi, at $\%$

\begin{tabular}{|c|c|c|c|c|}
\hline \multicolumn{5}{|c|}{$\mathrm{NiTi}$ carbon contamination nano-layer, at $\%$} \\
\hline & $\begin{array}{c}\mathrm{C}-\mathrm{C} \\
\mathrm{C}-\mathrm{H}\end{array}$ & $\begin{array}{c}\mathrm{C}-\mathrm{OH} \\
\mathrm{C}-\mathrm{O}-\mathrm{C}\end{array}$ & $\mathrm{C}=\mathrm{O}$ & $\mathrm{O}-\mathrm{C}=\mathrm{O}$ \\
\hline $\mathrm{C} \mathrm{1s}, \mathrm{eV}$ & 284,8 & $+1,5 \mathrm{eV}$ & $+2,9 \mathrm{eV}$ & $+4 \mathrm{eV}$ \\
\hline Carbon & 72,2 & 19,9 & 4,0 & 3,9 \\
\hline Oxide & - & $<2,8 ; 5,5>$ & 1,1 & 2,2 \\
\hline
\end{tabular}

On the basis of high resolution XPS spectra of oxygen $(\mathrm{O} 1 \mathrm{~s})$ and carbon $(\mathrm{C} 1 \mathrm{~s})$ it is possible to separate the contamination layer and the PEO coating. The total chemical composition of PEO coating, which was measured by the XPS technique, is shown in Tab. 4. Oxygen bonded with carbon (contamination layer), presented in Tab. 5, was separated from that one bonded with the chemical elements of passive layers (Tab. 6). The carbon-oxygen ratio in the contamination layer was solved based on the stoichiometric rules. Carbon contamination layer formed on the NiTi surface consists of about 80 at $\%$ of carbon and 20 at $\%$ of oxygen. Additionally, the $\mathrm{Cu} / \mathrm{P}, \mathrm{Cu} / \mathrm{Ti}, \mathrm{Ti} / \mathrm{P}$ and $\mathrm{Cu} /(\mathrm{Ti}+\mathrm{Ni}+\mathrm{P})$ coefficients were found to allow comparing the obtained coating with other ones proposed by the other researchers $[19,20]$ :

$\frac{\mathrm{Cu}}{\mathrm{P}}=0,07 ; \frac{\mathrm{Cu}}{\mathrm{Ti}}=1,67 ; \frac{\mathrm{Ti}}{\mathrm{P}}=0,04 ; \frac{\mathrm{Cu}}{\mathrm{Ti}+\mathrm{Ni}+\mathrm{P}}=0,05$

Table 6 PEO coating formed on NiTi, at\% (after removal of carbon contaminations)

\begin{tabular}{|c|c|c|c|c|}
\hline \multicolumn{5}{|c|}{$10 \mathrm{~nm}$ of PEO layer on NiTi, at\% } \\
\hline Titanium & Nickel & Copper & Phosphorus & Oxygen \\
\hline 1,2 & 0,9 & 2,0 & 27,5 & 68,4 \\
\hline
\end{tabular}

Based on the spectra shown in Fig. 9, it is possible to note that the binding energies of $\mathrm{Ti} 2 \mathrm{p}_{3 / 2}$ and $\mathrm{Ti} 2 \mathrm{p}_{1 / 2}$, are equaling to $460,4 \mathrm{eV}$ and $466 \mathrm{eV}$, respectively. Those binding energies suggest in fact the presence of titanium on the fourth stage of oxidation $\left(\mathrm{Ti}^{4+}\right)$ in the surface layer $[18,19]$. On the basis of $\mathrm{P} 2 \mathrm{p}$ spectrum, where the maximum is observed at $134,1 \mathrm{eV}$, one can assume the presence of titanium and/or copper and/or nickel phosphates in the PEO coating. The $\mathrm{Cu} 2 \mathrm{p}$ spectrum has three local maxima for the following binding energies: 935,3 eV, 939,2 eV and 943,95 eV. All the presented maxima of $\mathrm{Cu} 2 \mathrm{p}$ spectrum can be interpreted as the copper on the second stage of oxidation, i.e. $\mathrm{Cu}^{2+}$. The 
maximum of $\mathrm{Ni} 2 \mathrm{p}$ spectrum at the binding energy equaling $857,5 \mathrm{eV}$ can be interpreted as nickel phosphate. Summing up, it should be noticed that the surface layer consists mainly of $\mathrm{Ti}^{4+}, \mathrm{Cu}^{2+}, \mathrm{Ni}^{2+}$ and $\mathrm{PO}_{4}{ }^{3-}$, which may form the compounds such as $\mathrm{Ti}_{3}\left(\mathrm{PO}_{4}\right)_{4} \cdot \mathrm{Cu}_{3}\left(\mathrm{PO}_{4}\right)_{2} \cdot \mathrm{Ni}_{3}\left(\mathrm{PO}_{4}\right)_{2}$.

\section{Conclusions}

Based on the experimental results, the following conclusions can be formulated:

- it is possible to create a porous coating on NiTi alloy, enriched with copper ions; for this purpose the Plasma Electrolytic Oxidation (PEO) at voltage of $450 \mathrm{~V}$ was used and the process was carried out in the electrolyte containing concentrated $\mathrm{H}_{3} \mathrm{PO}_{4}$ within $\mathrm{Cu}\left(\mathrm{NO}_{3}\right)_{2}$ in the amount higher than $1,6 \mathrm{~mol} / \mathrm{L}$

- the porous PEO coating obtained in the electrolyte containing copper nitrate in an amount higher than $1,6 \mathrm{~mol} / \mathrm{L}$ consists mainly of copper-titanium-nickel phosphates

- a negative aspect of the coating is the emergence of carcinogenic nickel appearing inside, fortunately in very small quantities, i.e. below $1 \mathrm{at} \%$, in comparison with matrix

- the obtained PEO coating consists mainly of $\mathrm{Ti}^{4+}$, $\mathrm{Cu}^{2+}, \mathrm{Ni}^{2+}$ and $\mathrm{PO}_{4}{ }^{3-}$.

\section{Acknowledgements}

Prof. Dr.-Ing. Winfried Malorny and Dr. Torsten Barfels from Hochschule Wismar, Germany are thankful for providing access to the SEM/EDS apparatus allowing performing a part of the studies reported herewith.

\section{References}

[1] Hryniewicz, T.; Rokosz, K. Investigation of selected surface properties of AISI 316L SS after magnetoelectropolishing. // Materials Chemistry and Physics. 122, 1(2010), pp. 169-174. DOl: 10.1016/j.matchemphys.2010.02.055

[2] Hryniewicz, T.; Rokicki, R.; Rokosz, K. Co-Cr alloy corrosion behaviour after electropolishing and "magnetoelectropolishing" treatments. // Surface and Coatings Technology. 62, 17-18(2008), pp. 3073-3076. DOI: 10.1016/j.matlet.2008.01.130

[3] Hryniewicz, T.; Konarski, P.; Rokosz, K.; Rokicki, R. SIMS analysis of hydrogen content in near surface layers of AISI 316L SS after electrolytic polishing under different conditions. // Surface and Coatings Technology. 205, 1718(2011), pp. 4228-4236. DOI: 10.1016/j.surfcoat.2011.03.024

[4] Rokicki, R.; Hryniewicz, T.; Pulletikurthi, C.; Rokosz, K.; Munroe, N. Towards a Better Corrosion Resistance and Biocompatibility Improvement of Nitinol Medical Devices, // Journal of Materials Engineering and Performance. 24, 4(2015), pp. 1634-1640. DOI: 10.1007/s11665-015-1429-x

[5] Hryniewicz, T.; Rokosz, K.; Zschommler Sandim, H. R. SEM/EDX and XPS studies of niobium after electropolishing. // Applied Surface Science. 263, (2012), pp. 357-361. DOI: 10.1016/j.apsusc.2012.09.060

[6] Hryniewicz, T.; Rokosz, K.; Rokicki, R.; Prima, F. Nanoindentation and XPS Studies of Titanium TNZ Alloy after Electrochemical Polishing in a Magnetic Field. // Materials. 8, 1(2015), pp. 205-215. DOI: 10.3390/ma8010205
[7] Rokicki, R.; Hryniewicz, T. Enhanced oxidation-dissolution theory of electropolishing. // Transactions of the Institute of Metal Finishing. 90, 4(2012), pp. 188-196. DOI: 10.1179/0020296712Z.00000000031

[8] Simka, W.; Sowa, M.; Socha, R. P.; Maciej, A.; Michalska, J. Anodic oxidation of zirconium in silicate solutions. // Electrochimica Acta. 104, (2013), pp. 518-525. DOI: 10.1016/j.electacta.2012.10.130

[9] Simka, W.; Sadowski, A.; Warczak, M.; Iwaniak, A.; Dercz, G.; Michalska, J.; Maciej, A. Modification of titanium oxide layer by calcium and phosphorus. // Electrochimica Acta. 56, 24(2011), pp. 8962-8968. DOI: 10.1016/j.electacta.2011.07.129

[10] Simka, W.; Nawrat, G.; Chlode, J.; Maciej, A.; Winiarski, A.; Szade, J.; Radwanski, K.; Gazdowicz, J. Electropolishing and anodic passivation of Ti6Al7 Nb alloy. // Przemysł Chemiczny. 90, 1(2011), pp. 84-90.

[11] Yu, S.; Yu, Z.; Wang, G.; Han, J.; Ma, X.; Dargusch, M. S., Preparation and osteoinduction of active micro-arc oxidation films on Ti-3Zr-2Sn-3Mo-25Nb alloy. // Trans. Nenferrous Met. Soc. China. 21, (2011), pp. 573-580. DOI: 10.1016/S1003-6326(11)60753-X

[12] Sowa, M.; Kazek-Kesik, A.; Socha, R. P.; Dercz, G., Michalska, J.; Simka, W. Modification of tantalum surface via plasma electrolytic oxidation in silicate solutions. // Electrochimica Acta. 114, (2013), pp. 627-636. DOI: 10.1016/j.electacta.2013.10.047

[13] Jin, F. Y.; Tong, H. H.; Shen, L. R.; Wang, K.; Chu, P. K. Micro-structural and Dielectric Properties of Porous TiO2 Films Synthesized on Titanium Alloys by Micro-Arc Discharge Oxidization. // Materials Chemistry and Physics. 100, 1(2006), pp. 31-33. DOI: 10.1016/j.matchemphys.2005.12.001

[14] Jelinek, M.; Kocourek, T.; Remsa, J.; Weiserová, M.; Jurek, K.; Mikšovský, J.; Strnad, J.; Galandáková, A.; Ulrichová, J. Antibacterial, cytotoxicity and physical properties of laser - Silver doped hydroxyapatite layers. // Materials Science and Engineering: C. 33, 3(2013), pp. 1242-1246. DOI: 10.1016/j.msec.2012.12.018

[15] Rokosz, K.; Hryniewicz, T.; Dalibor, M.; Raaen, S.; Valiček, J.; Dudek, Ł.; Harničarova, M. SEM, EDS AND XPS Analysis of the Coatings Obtained on Titanium after Plasma Electrolytic Oxidation in Electrolytes Containing Copper Nitrate. // Materials. 9, 318(2016), pp. 1-12. DOI: 10.3390/ma9050318

[16] Rokosz, K.; Hryniewicz, T.; Dudek, Ł.; Matýsek, D.; Valíček, J.; Harničárová, M. SEM and EDS analysis of surface layer formed on titanium after plasma electrolytic oxidation in phosphoric acid with the addition of copper nitrate, (NanoOstrava 2015). // Journal of Nanoscience and Nanotechnology. 16, (2016), pp. 7814-7817. DOI: 10.1166/jnn.2016.12558

[17] Rokosz, K.; Hryniewicz, T.; Raaen, S.; Chapon, P. Investigation of porous coatings obtained on $\mathrm{Ti}-\mathrm{Nb}-\mathrm{Zr}-\mathrm{Sn}$ alloy biomaterial by plasma electrolytic oxidation: characterisation and modelling. // The International Journal of Advanced Manufacturing Technology. 87, (2016), pp. 3497-3512. DOI: 10.1007/s00170-016-8692-3

[18] Rokosz, K.; Hryniewicz, T.; Raaen, S. Development of Plasma Electrolytic Oxidation for improved Ti6A14V biomaterial surface properties. // The International Journal of Advanced Manufacturing Technology. 81, 9-12(2015), 13 pages, DOI: $10.1007 / \mathrm{s} 00170-015-8086-y$

[19] Rokosz K., Hryniewicz T., Raaen S., Chapon P., Development of copper-enriched porous coatings on ternary $\mathrm{Ti}-\mathrm{Nb}-\mathrm{Zr}$ alloy by Plasma Electrolytic Oxidation, The International Journal of Advanced Manufacturing Technology. 80, 440(2016), pp. 1-13. DOI: 10.1007/s00170016-9206-z 
[20] Rokosz, K.; Hryniewicz, T.; Chapon, P.; Raaen, S.; Zschommler Sandim, H. R. XPS and GDOES characterisation of porous coating enriched with copper and calcium obtained on Tantalum via Plasma Electrolytic Oxidation. // Journal of Spectroscopy. 2016, Article ID 7093071, 7 pages, DOI: 10.1155/2016/7093071

[21] Rokosz, K.; Hryniewicz, T.; Raaen, S.; Chapon, P.; Dudek, Ł. GDOES, XPS and SEM with EDS analysis of porous coatings obtained on Titanium after Plasma Electrolytic Oxidation. // Surface and Interface Analysis. 2016.

[22] Rokosz, K.; Hryniewicz, T. Plasma Electrolytic Oxidation as a modern method to form porous coatings enriched in phosphorus and copper on biomaterials. // World Scientific News. 35, (2016), pp. 44-61.

[23] Rokosz, K.; Hryniewicz, T.; Chapon, P.; Dudek, Ł. A new approach to porous PEO coating sub-layers determination on the basis of GDOES signals. // World Scientific News, 57, (2016), pp. 289-299.

[24] Mishra, G.; Dash, B.; Pandey, S.; Mohanty, P. P. Antibacterial actions of silver nanoparticles incorporated $\mathrm{Zn}-\mathrm{Al}$ layered double hydroxide and its spinel. // Journal of Environmental Chemical Engineering. 1, 4(2013), pp. 1124-1130. DOI: 10.1016/j.jece.2013.08.031

[25] Rajendrana, A.; Pattanayak, D. K. Silver incorporated antibacterial, cell compatible and bioactive titania layer on Ti metal for biomedical applications. // RSC Advances. 106, 4(2014), pp. 61444-61455. DOI: 10.1039/C4RA13107J

[26] Trujillo, N. A.; Oldinski, R. A.; Mad, H.; Bryers, J. D.; Williams, J. D.; Popat, K. C. Antibacterial effects of silverdoped hydroxyapatite thin films sputter deposited on titanium. // Materials Science and Engineering: C. 32, 8(2012), pp. 2135-2144. DOI: 10.1016/j.msec.2012.05.012

[27] Xiangyu, Zhang; Xiaobo, Huang; Yong, Ma; Naiming, Lin; Ailan, Fan; Bin, Tang. Bactericidal behavior of $\mathrm{Cu}-$ containing stainless steel surfaces. // Applied Surface Science. 258, (2012), pp. 10058-10063. DOl: 10.1016/j.apsusc.2012.06.074

[28] Xiaohong, Yao; Xiangyu, Zhang; Haibo, Wu; Linhai, Tian; Yong, Ma; Bin Tang. Microstructure and antibacterial properties of $\mathrm{Cu}$-doped $\mathrm{TiO} 2$ coating on titanium by microarc oxidation. // Applied Surface Science. 292, (2014), pp. 944-947. DOI: 10.1016/j.apsusc.2013.12.083

[29] Hempel, F.; Finke, B.; Zietz, C.; Bader, R.; Weltmann, K.D.; Polak, M. Antimicrobial surface modification of titanium substrates by means of plasma immersion ion implantation and deposition of copper. // Surface \& Coatings Technology. 256, (2014), pp. 52-58. DOI: 10.1016/j.surfcoat.2014.01.027

\section{Authors' addresses}

Krzysztof Rokosz, DSc PhD, Assoc. Prof.

Division of BioEngineering and Surface Electrochemistry, Faculty of Mechanical Engineering, Koszalin University of Technology, Racławicka 15-17, 75-620 Koszalin, Poland E-mail: rokosz@tu.koszalin.pl

Tadeusz Hryniewicz, DSc PhD ME CE, Professor (Corresponding author)

Division of BioEngineering and Surface Electrochemistry, Faculty of Mechanical Engineering,

Koszalin University of Technology,

Racławicka 15-17, PL 75-620 Koszalin, Poland

E-mail: Tadeusz.Hryniewicz@tu.koszalin.pl

Steinar Raaen, PhD

Department of Physics,

Norwegian University of Science and Technology (NTNU), Realfagbygget E3-124 Høgskoleringen 5, NO 7491 Trondheim E-mail: steinar.raaen@ntnu.no 